\title{
Snow chemistry across Antarctica
}

N. BERTLER, ${ }^{1}$ P.A. MAYEWSKI ${ }^{2}$ A. ARISTARAIN ${ }^{3}$ P. BARRETT, ${ }^{1}$ S. BECAGLI, ${ }^{4}$ R. BERNARDO, ${ }^{5}$ S. BO, ${ }^{6}$ XIAO C., ${ }^{7 *}$ M. CURRAN, ${ }^{8}$ QIN D.,${ }^{9}$ D. DIXON, ${ }^{2}$ F. FERRON, ${ }^{5}$ H. FISCHER, ${ }^{10}$ M. FREY, ${ }^{11}$ M. FREZZOTTI, ${ }^{12}$ F. FUNDEL, ${ }^{10}$ C. GENTHON, ${ }^{13}$ R. GRAGNANI, ${ }^{12}$ G. HAMILTON, ${ }^{2}$ M. HANDLEY, ${ }^{2}$ S. HONG, ${ }^{14}$ E. ISAKSSON, ${ }^{15}$ KANG J., ${ }^{6}$ REN J., ${ }^{9}$ K. KAMIYAMA, ${ }^{16}$ S. KANAMORI, ${ }^{16}$ E. KÄRK ÄS, ${ }^{17}$ L. KARLÖF, ${ }^{15}$ S. KASPARI, ${ }^{2}$ K. KREUTZ, ${ }^{2}$ A. KURBATOV, ${ }^{2}$ E. MEYERSON ${ }^{2}{ }^{2}$ Y. MING, ${ }^{6}$ ZHANG M., $^{9}$ H. MOTOYAMA,${ }^{16}$ R. MULVANEY, ${ }^{18}$ H. OERTER, ${ }^{10}$ E. OSTERBERG, ${ }^{2}$ M. PROPOSITO, ${ }^{12}$ A. PYNE, ${ }^{1}$ U. RUTH, ${ }^{10}$ J. SIMÕES, ${ }^{5}$ B. SMITH, ${ }^{8}$ S. SNEED, ${ }^{2}$ K. TEINILÄ, ${ }^{19}$ F. TRAUFETTER, ${ }^{10}$ R. UDISTI, ${ }^{4}$ A. VIRKKULA, ${ }^{17}$ O. WATANABE, ${ }^{16}$ B. WILLIAMSON, ${ }^{2}$ J-G. WINTHER, ${ }^{15}$ LI Y., $^{6}$ E. WOLFF, ${ }^{18}$ LI Z., ${ }^{9}$ A. ZIELINSKI ${ }^{2}$

${ }^{1}$ Antarctic Research Centre, Victoria University, PO Box 600, Wellington, New Zealand E-mail: Nancy.Bertler@vuw.ac.nz

${ }^{2}$ Climate Change Institute, University of Maine, Orono, ME 04469, USA

${ }^{3}$ Laboratorio de Estratigrafia Glaciar y Geoquimica del Agua y de la Nieve - Conicet, CC 131, 5500 Mendoza, Argentina

${ }^{4}$ Chemistry Department - Analytical Chemistry, Scientific Pole, University of Florence, Via della Lastruccia 3, I-50019 Sesto Fiorentino (Florence), Italy

${ }^{5}$ Núcleo de Pesquisas Antárticas e Climáticas, Universidade Federal do Rio Grande do Sul, Avenida Bento Gonçalves 9500, 91.501-970 Porto Alegre, Brazil

${ }^{6}$ Polar Research Institute of China, Shanghai 200129, China

${ }^{7}$ Institute of Climate and Environment, Chinese Academy of Meteorological Sciences, 46 Zhongguancun South Avenue, Beijing 100081, China

${ }^{8}$ Australian Antarctic Division/Antarctic Climate and Ecosystems CRC, Private Bag 80, Hobart, Tasmania 7001, Australia

${ }^{9}$ Cold and Arid Regions Environmental and Engineering Research Institute, Chinese Academy of Sciences, 260 Donggang West Road, Lanzhou 730000, China

${ }^{10}$ Alfred Wegener Institute for Polar and Marine Research, Columbusstrasse, D-27568 Bremerhaven, Germany

${ }^{11}$ Department of Hydrology and Water Resources, PO Box 210011, The University of Arizona, Tucson, AZ 85271-0011, USA

${ }^{12}$ ENEA, Progetto Clima, Centro Ricerche Casaccia, I-00060 S. Maria Galeria (Roma), Italy

${ }^{13}$ Laboratoire de Glaciologie et Géophysique de l'Environnement, 54 rue Molière, BP 96, 38402 Saint-Martin-d'Hères Cedex, France

${ }^{14}$ Korea Polar Research Institute, Korea Ocean Research and Development Institute, PO Box 29, Ansan, 425-600, Seoul, Korea

${ }^{15}$ Norwegian Polar Institute, Polarmiljøsenteret, NO-9296 Tromsø, Norway

${ }^{16}$ National Institute of Polar Research, Kaga, Itabashi-ku, Tokyo 173-8515, Japan

${ }^{17}$ Division of Geophysics, Department of Physical Sciences, PO Box 64, University of Helsinki, FIN-00014 Helsinki, Finland ${ }^{18}$ British Antarctic Survey, Natural Environment Research Council, Madingley Road Cambridge CB3 OET, UK

${ }^{19}$ Finnish Meteorological Institute, Air Quality Research, Sahaajankatu 20E, FIN-00810 Helsinki, Finland

ABSTRACT. An updated compilation of published and new data of major-ion (Ca, $\mathrm{Cl}, \mathrm{K}, \mathrm{Mg}, \mathrm{Na}, \mathrm{NO}_{3}$, $\mathrm{SO}_{4}$ ) and methylsulfonate (MS) concentrations in snow from 520 Antarctic sites is provided by the national ITASE (International Trans-Antarctic Scientific Expedition) programmes of Australia, Brazil, China, Germany, Italy, Japan, Korea, New Zealand, Norway, the United Kingdom, the United States and the national Antarctic programme of Finland. The comparison shows that snow chemistry concentrations vary by up to four orders of magnitude across Antarctica and exhibit distinct geographical patterns. The Antarctic-wide comparison of glaciochemical records provides a unique opportunity to improve our understanding of the fundamental factors that ultimately control the chemistry of snow or ice samples. This paper aims to initiate data compilation and administration in order to provide a framework for facilitation of Antarctic-wide snow chemistry discussions across all ITASE nations and other contributing groups. The data are made available through the ITASE web page (http:// www2.umaine.edu/itase/content/syngroups/snowchem.html) and will be updated with new data as they are provided. In addition, recommendations for future research efforts are summarized.

*Also at: Cold and Arid Regions Environmental and Engineering Research Institute, Chinese Academy of Sciences, 260 Donggang West Road, Lanzhou 730000, China. 


\section{INTRODUCTION}

'Ice cores provide the most direct and highly resolved records of (especially) atmospheric parameters for the last $1,000,000$ years' (EPICA community, 2004). While ice-core chemistry analyses have revolutionized our knowledge on the working of the climate system and its variability through time (Legrand and Mayewski, 1997; Mayewski and White, 2002), an improved understanding of the fundamental factors that ultimately control the chemistry of a snow or ice sample will allow even more detailed and accurate interpretation of glaciochemical records reconstructing past climate conditions with near-instrumental quality.

To reach this understanding, it is necessary to determine individual sources and pathways of aerosols, mechanisms that control precipitation efficiency as well as post-depositional effects (Legrand and Mayewski, 1997). Comparing snow chemistry at different sites and investigating the processes leading to spatial differences in snow chemistry help to improve our understanding of temporal variability and teleconnections. Here, we provide an updated summary of available data from 520 sites in Antarctica, developed by the International Trans-Antarctic Scientific Expedition (ITASE), with the goal of providing this new dataset along with research recommendations to the wider ice-core community, in order to stimulate and focus the discussion towards a more comprehensive data interpretation.

\section{BACKGROUND}

ITASE has as its primary aim the collection and interpretation of a continental-wide array of environmental parameters assembled through the coordinated efforts of scientists from several nations' (Science and Implementation Plan, 1990, http://www2.ume.maine.edu/itase/content/ scie_plan/intro.html). During the Seventh International Symposium on Antarctic Glaciology, in Milan, Italy, in 2003, the ITASE community established seven synthesis groups, of which this group - the ITASE Chemistry Synthesis group - is coordinating the compilation and interpretation of the spatial variability in snow and ice chemistry across the continent to address the knowledge gap on factors governing the variability of ice-core chemistry in Antarctica. A twostep approach was adopted. Firstly, broad patterns in Antarctic snow chemistry are investigated using all available reliable data (this paper). This will allow the strategy to be formulated for the second step, in which the group will focus on individual time periods in order to investigate the causes for changes in chemistry patterns (future papers). This will be achieved by contrasting, for example, El Niño with La Niña years or studying the years before and after volcanic eruptions, such as the recent Pinatubo (Philippines) event.

In this first step, we summarize new and previously published data and provide recommendations for future common efforts. The new data are provided by the national ITASE programmes of Australia, Brazil, China, Germany, Italy, Japan, Korea, New Zealand, Norway, the United Kingdom, the United States and the national Antarctic programme of Finland.

\section{DATA SELECTION CRITERIA}

Previous glaciochemical surveys showed that careful data selection for an Antarctic-wide comparison is important (Mayewski and others, 1992; Mulvaney and Wolff, 1994;
Wagenbach, 1996; Legrand and Mayewski, 1997; Wolff and others, 1998a, b; Kreutz and Mayewski, 1999; Kreutz and others, 1999; Stenberg and others, 1999). Data from 520 sites are summarized here and can be obtained from the ITASE Chemistry Synthesis group web page (http://www2. umaine.edu/itase/content/syngroups/snowchem.html). While the laboratory procedures of the individual groups are of high standard, no cross-evaluation has yet been undertaken. To obtain further information on individual datasets, contact details are provided along with the data.

Because Antarctic glaciochemistry shows large seasonal variability (Gow, 1965; Sigg and Neftel, 1988; Solomon and Keys, 1992; Legrand and Mayewski, 1997; Curran and others, 1998; Wolff and others, 1998a; Kreutz and others, 1999; Bertler and others, 2004b), it is desirable for any continent-wide comparison to use either well-dated (subannual) records or multi-year averages. The achievable level of age control of ice-core records is dependent on many factors, but particularly on annual accumulation (and sampling resolution) and therefore varies greatly across Antarctica. Of the 520 available data sources, 194 records are reliably identified as multi-year samples. The remaining records are predominantly surface snow samples collected along transects, and thus are an important contribution to determine aerosol sources. For the comparison of new ITASE data, however, we decided to aim in this first step for 5 year averages. This allows short records to be included while eliminating seasonal variability. A survey of ITASE metadata indicates that the 5 year interval most represented in the currently available dataset is 1992-97. At present, 45 sites provide well-dated chemistry measurements for this time period. This interval coincides with the Pinatubo volcanic eruption, and therefore provides an opportunity to study the effect of volcanic eruptions in future papers when time series are considered.

A second fundamental decision is whether to use concentration or flux data (Kreutz and others, 2000). Due to the spatially variable influence of dry and wet deposition across Antarctica and the difficulty of obtaining reliable, high-resolution annual snow accumulation measurements, concentration data are preferred over flux. However, as more accumulation data become available, the influence of spatially and temporally varying snow accumulation leading to varying contributions of wet vs dry deposition should be investigated further. This can be achieved by merging the data of this group with the currently compiled datasets of the ITASE/ISMASS (Ice Sheet Mass Balance and Sea Level programme) Mass Balance and Atmospheric Chemistry Synthesis groups.

In the metadata survey, information on all glaciochemical analyses has been compiled. Here, we focus on major ions: sodium $(\mathrm{Na})$, magnesium $(\mathrm{Mg})$, calcium $(\mathrm{Ca})$, potassium $(\mathrm{K})$, chloride $(\mathrm{Cl})$, nitrate $\left(\mathrm{NO}_{3}\right)$, sulphate $\left(\mathrm{SO}_{4}\right)$ and methanesulfonate (MS). An Antarctic-wide comparison of other species, such as trace elements, organic acids, and particles, is hampered by the limited number of data points currently available. However, growing interest and improved analytical methods will enable us to incorporate such data in the near future.

\section{DATA EVALUATION AND PRESENTATION}

As Antarctica exhibits strong spatial contrasts, it is important to evaluate how well the sampled locations represent 

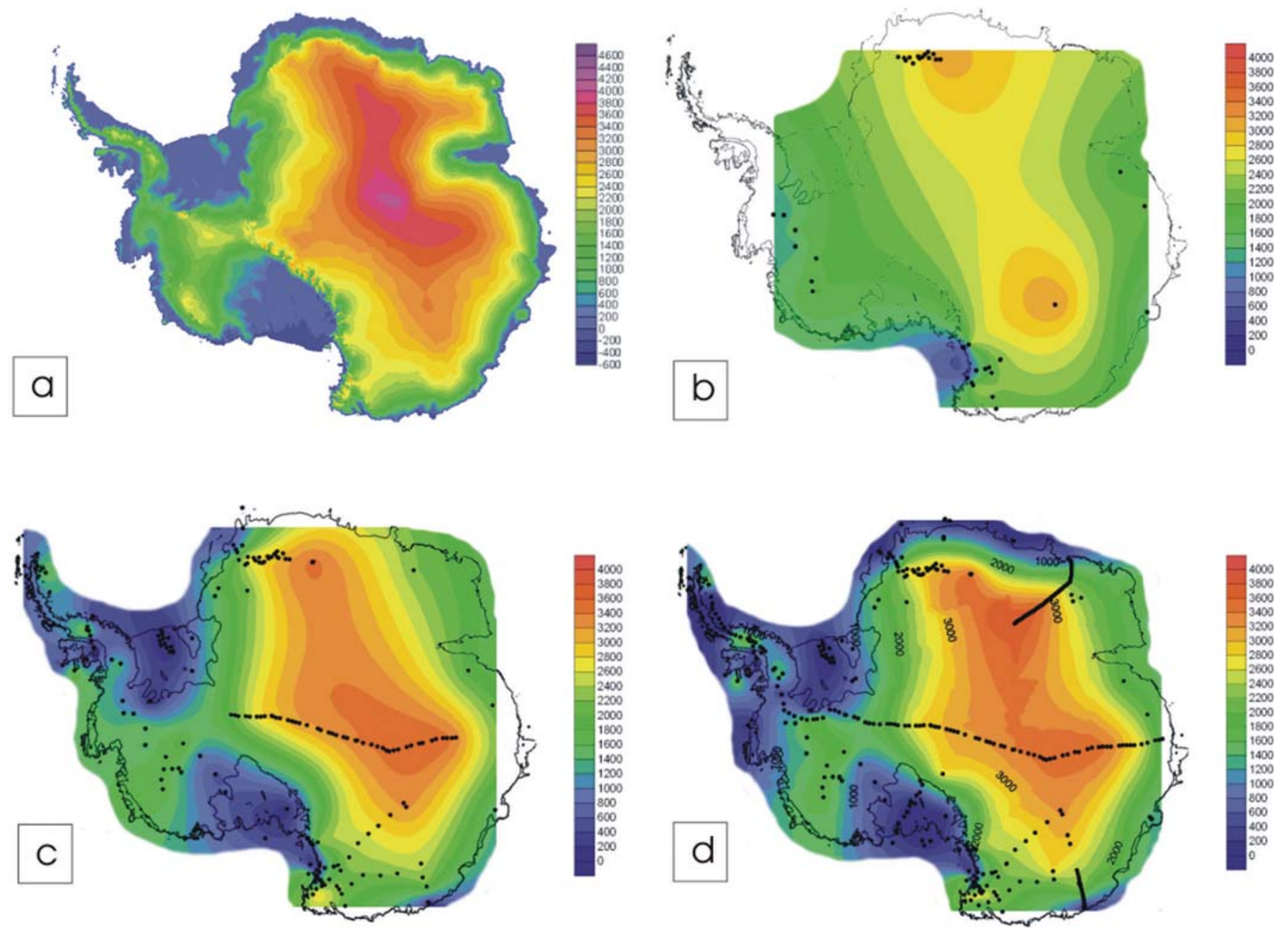

Fig. 1. Reconstructed topography of Antarctica, derived from (a) RAMP $5 \mathrm{~km}$ elevation model (Liu and others, 2001); (b) sample locations providing data for the period 1992-97; (c) sample locations providing multi-year averages; (d) all glaciological sample locations.

regional- to continent-scale gradients. Most parameters (e.g. elevation, distance from the sea, annual accumulation) change simultaneously along many transects and are therefore difficult to assess individually. The comparison between the Antarctic topography, as inferred by the RADARSAT Antarctic Mapping Project (RAMP) $5 \mathrm{~km}$ elevation model (Liu and others, 2001) (Fig. 1a), and the reconstructed surface using only elevation information from the sampled sites provides a means to evaluate how well Antarctic geographic features are represented by the sampled locations. The reconstructed surfaces in Figure $1 \mathrm{~b}-\mathrm{d}$ are calculated using the interpolation method of linear kriging between sampling sites. In Figure $1 \mathrm{~b}$ the Antarctic surface is reconstructed using only sites that provide data from the chosen 1992-97 time period (45 data points). While the data are clustered and separated by large geographical gaps, they represent contemporary glaciochemical concentration, generally excluding time-driven factors, such as climate variability. The reconstructed topography lacks many of the significant Antarctic features (e.g. neither ice shelf nor the Antarctic Peninsula is yet represented). A number of sites provide 5 year averages for slightly different time periods or have an associated dating error of more than \pm 1 year. Incorporating these sites enlarges the database significantly. In Figure 1c the reconstructed topography using all multi-year data is shown (194 data points). While main geographical features, such as the East and West Antarctic ice sheets, the Ross and Filchner-Ronne Ice Shelves are represented, other significant details such as the Transantarctic Mountains, the Antarctic Peninsula and the Lambert Glacier system are poorly or not represented. The reconstructed topography in Figure $1 \mathrm{~d}$ incorporates all available data (520 data points), including non-annual samples. This is the most comprehensive dataset currently available. As the data do not all represent the same time period or might represent only seasons, their interpretation in an Antarctic-wide comparison requires careful attention. Although the reconstructed map incorporating all available data is more detailed than Figure 1c, it still lacks important elements across large regions of the Antarctic continent. Overall, this comparison highlights the need for many more traverses to provide better coverage, especially of well-dated, multi-year, contemporary time series.

\section{ION CONCENTRATION VS ELEVATION}

As discussed above, many site physical characteristics influencing glaciochemistry change simultaneously, either geographically or temporally. These include annual accumulation, elevation and distance from the sea. Accurate, high-resolution annual accumulation data are difficult to obtain, as they require high-resolution dating and density measurements. Furthermore, there are no well-documented, 



Fig. 2. Relationship between multi-year ion concentration data and elevation: (a) $\mathrm{Na}$; (b) $\mathrm{Cl}$; (c) $\mathrm{Cl} / \mathrm{Na}$ ratio; (d) $\mathrm{NO}_{3}$; (e) $\mathrm{SO}_{4}$; (f) $\mathrm{MS}$; (g) $\mathrm{Ca}$; (h) Mg; and (i) K. All species are plotted on a logarithmic scale, except for (c) which is plotted on a linear scale. The logarithmic trends shown are significant on the $99.9 \%$ level.

straightforward linear associations between chemistry and accumulation rate. In order to determine distance from the sea, it is necessary to understand the pathway of the precipitating air mass for both wet and dry deposition. Local atmospheric circulation patterns can be highly variable and might change true distance to the sea from $10 \mathrm{~km}$ to $1000 \mathrm{~km}$ depending on the pathway of the air mass (e.g. Bertler and others, 2004a; Xiao and others, 2004; Kaspari and others, 2005). Furthermore, large seasonal changes in sea-ice cover further complicate the measurement of true distance to the sea. One parameter that is relatively easy to obtain and does not change significantly over short time periods is elevation.

However, as annual accumulation and distance from the sea exhibit a correlation with elevation in Antarctica, any observed patterns are likely to be caused by a varying combination of all three. Correlation between ion concentration and elevation is shown in Figure 2. Ion concentration variability across Antarctica exhibits an amplitude of up to four orders of magnitude. Therefore, ion concentrations are plotted on logarithmic scales, with the exception of the $\mathrm{Cl}$ / Na ratio.

The correlations between elevation and $\mathrm{Na}$ or $\mathrm{Cl}$ (Fig. 2a and b) show a statistically significantly inverse relationship (logarithmic) of decreasing ion concentration with increasing altitude of $r=-0.73$ and $r=-0.51$, respectively. Furthermore, the scatter in both datasets is larger at lower elevation than at higher locations. When correlating the $\mathrm{Cl} /$ $\mathrm{Na}$ ratio with elevation $(r=0.56)$, sites below $2000 \mathrm{~m}$ predominantly show values close to the marine ratio of 1.8 (Warneck, 1988), while the scatter in the data increases significantly above $2000 \mathrm{~m}$, reaching values of 
up to 20 (Fig. 2c). This confirms that sites below $2000 \mathrm{~m}$ are predominantly influenced by sea salt, and also suggests no significant post-depositional aerosol loss or enrichment. The larger scatter with increasing elevation is indicative of a number of potential processes leading to relative enrichment or depletion of either species (Gayley and Ram, 1985; Mulvaney and Peel, 1988; Mulvaney and Wolff, 1994; De Angelis and Legrand, 1995; Yang and others, 1996a; Legrand and Mayewski, 1997; Kreutz and others, 1998; Stenberg and others, 1998; Wagenbach and others, 1998b; Wolff and others, 1998a, b; Kreutz and Mayewski, 1999; Udisti and others, 1999; Kreutz and others, 2000; Aristarain and Delmas, 2002; Proposito and others, 2002; Udisti and others, 2004; Becagli and others, 2005; Benassai and others, 2005).

No statistically significant correlation at the $99.9 \%$ significance level exists between elevation and $\mathrm{NO}_{3}$ (Fig. 2d). $\mathrm{NO}_{3}$ is predominantly a secondary aerosol, produced in the strato- and ionosphere. Processes leading to nitrate production in the higher atmosphere are thought to be stratospheric oxidation of $\mathrm{N}_{2} \mathrm{O}$, ionospheric dissociation of $\mathrm{N}_{2}$, and polar stratospheric clouds via $\mathrm{HNO}_{3}$. Additionally, lightening in the mid-latitudes produces the primary $\mathrm{NO}_{3}$ aerosol in the troposphere (Parker and others, 1981, 1982; Parker and Zeller, 1980; McKenzie and Johnston, 1984; Evans and others, 1985; Legrand and Delmas, 1986; Toon and others, 1986; Legrand and Kirchner, 1990; Mayewski and others, 1990; Qin and others, 1992; Solomon and Keys, 1992; Clausen, 1995; Wolff, 1995; Yang and others, 1996a, b; Legrand and Mayewski, 1997; Wagenbach and others, 1998a; Palmer and others, 2001). Higher $\mathrm{NO}_{3}$ concentrations are therefore expected within the boundary of the polar vortex due to the influence of upper atmospheric air masses. Furthermore, some post-depositional and photochemical mechanisms lead to $\mathrm{NO}_{3}$ loss, especially at lowaccumulation sites (De Angelis and Legrand, 1995; Legrand and Mayewski, 1997; Mulvaney and others, 1998; Wagnon and others, 1999; Röthlisberger and others, 2000, 2002; Jones and others, 2001; Wolff and others, 2002; Udisti and others, 2004), which partially offsets the trend towards higher $\mathrm{NO}_{3}$ in the Antarctic interior. As this effect takes place in the upper few metres of the snowpack, it is particularly important to compare not only contemporary $\mathrm{NO}_{3}$ data, but also samples derived from similar depths in the snow profile.

The correlation between $\mathrm{SO}_{4}$ and elevation also shows no statistically significant trend at the $99.9 \%$ significance level. While concentration data exhibit a more scattered pattern at lower elevations, total $\mathrm{SO}_{4}$ input seems largely independent of elevation. However, $\mathrm{SO}_{4}$ has many sources (Delmas and others, 1982; Wolff and Mulvaney, 1991; Mayewski and others, 1992; Mulvaney and Wolff, 1994; Legrand, 1995; Legrand and Mayewski, 1997; Minikin and others, 1998; Udisti and others, 1998, 1999; Becagli and others, 2005), and individual $\mathrm{SO}_{4}$ species might exhibit significant correlations with elevation. While primary aerosol $\mathrm{SO}_{4}$ species (sea spray) and secondary marine-biogenic $\mathrm{SO}_{4}$ should exhibit a rapid decrease with increasing elevation, volcanic $\mathrm{SO}_{4}$ aerosols enters through the upper atmosphere and therefore should have a stronger signal in the Antarctic interior. Furthermore, the volcanic input of $\mathrm{SO}_{4}$ often exceeds average $\mathrm{SO}_{4}$ input (Mayewski and others, 1995; Zielinski and others, 1997; Dixon and others, 2004). Because data used in this comparison represent different time periods, samples containing volcanic $\mathrm{SO}_{4}$ input have the potential to obscure an existing relationship, especially for the 1992-97 time period, which coincides with the Pinatubo 1991 eruption.

MS shows a statistically significant decrease with increasing elevation (Fig. 2f) of $r=-0.42$. While most ion species have multiple sources, MS is thought to have a single marine source and is derived via oxidation from planktonproduced DMS (dimethylsulfonate) in polar oceans (Mulvaney and others, 1992), which explains its anticorrelation with elevation. MS is observed to peak in summer, when biological activity is highest (Welch and others, 1993; Saltzman, 1995; Saltzman and others, 1997; Meyerson and others, 2002). Delmas and others (2003) and Weller and others (2004) describe a mechanism by which MS is lost to interstitial gaseous phase in the Antarctic interior, which might partially be responsible for the observed trend in Figure 3f. As for $\mathrm{NO}_{3}$, it is therefore important to investigate MS data in relationship to snow depth of the sample.

$\mathrm{Ca}, \mathrm{Mg}$ and $\mathrm{K}$ show an inverse relationship with decreasing concentration at higher-elevation sites (Fig. $3 g$ and $h$ ), with $r=-0.70$ and $r=-0.73, r=-0.52$ respectively. Furthermore, the scatter in the datasets appears higher at lower-elevations sites, especially for Ca. These species have local and global terrestrial, as well as marine sources. In the vicinity of ice-free areas, such as the McMurdo Dry Valleys, ion concentration is influenced from those local sources (Gayley and Ram, 1985; Aristarain and Delmas, 2002; Bertler and others, 2004b). Elsewhere, the input is dominated by sea-salt and global dust input (Shaw, 1979), with the former producing orders-of-magnitude higher concentrations than the latter, thus explaining the overall inverse relationship with elevation.

\section{SPATIAL ION CONCENTRATION VARIABILITY}

To further investigate the relationships observed in Figure 2, the geographical variability is discussed in Figures 3-11. The data for each species have been clustered into colour-coded classes. Due to the large amplitude of variability in ion concentration, the classes are distributed, not linearly, but, rather, according to data distribution. This is necessary because coastal regions, for example, show $\mathrm{Na}$ concentrations four orders of magnitude higher than those in the Antarctic interior (Fig. 3). As a result, a linear scale would under-represent the variability, with only one class for the entire Antarctic interior or for coastal sites. To compare sites within the Antarctic interior, or various coastlines, it is necessary to tune the classes so that variability at both low and high concentrations can be observed. The legend shows the percentage and number of data points contained in each class. Furthermore, data have been distinguished into three groups: well-dated data representing the period 1992-97 (solid circles), all other multi-year samples (solid triangles) and undated or non-annual samples (crosses). The colour coding for concentration classes is the same for all three groups.

Spatial variability of $\mathrm{Na}$ concentration is shown in Figure 3, ranging from 2 to $14680 \mathrm{ppb}$. As expected, the East Antarctic interior shows significantly lower values ( 2-30 ppb) than the coastal sites ( 75-14680 ppb). However, high values have also been reported from Marie Byrd Land at high elevation, and low concentrations in the vicinity of the East Antarctic coastlines (Kaiser-Wilhelm II. 


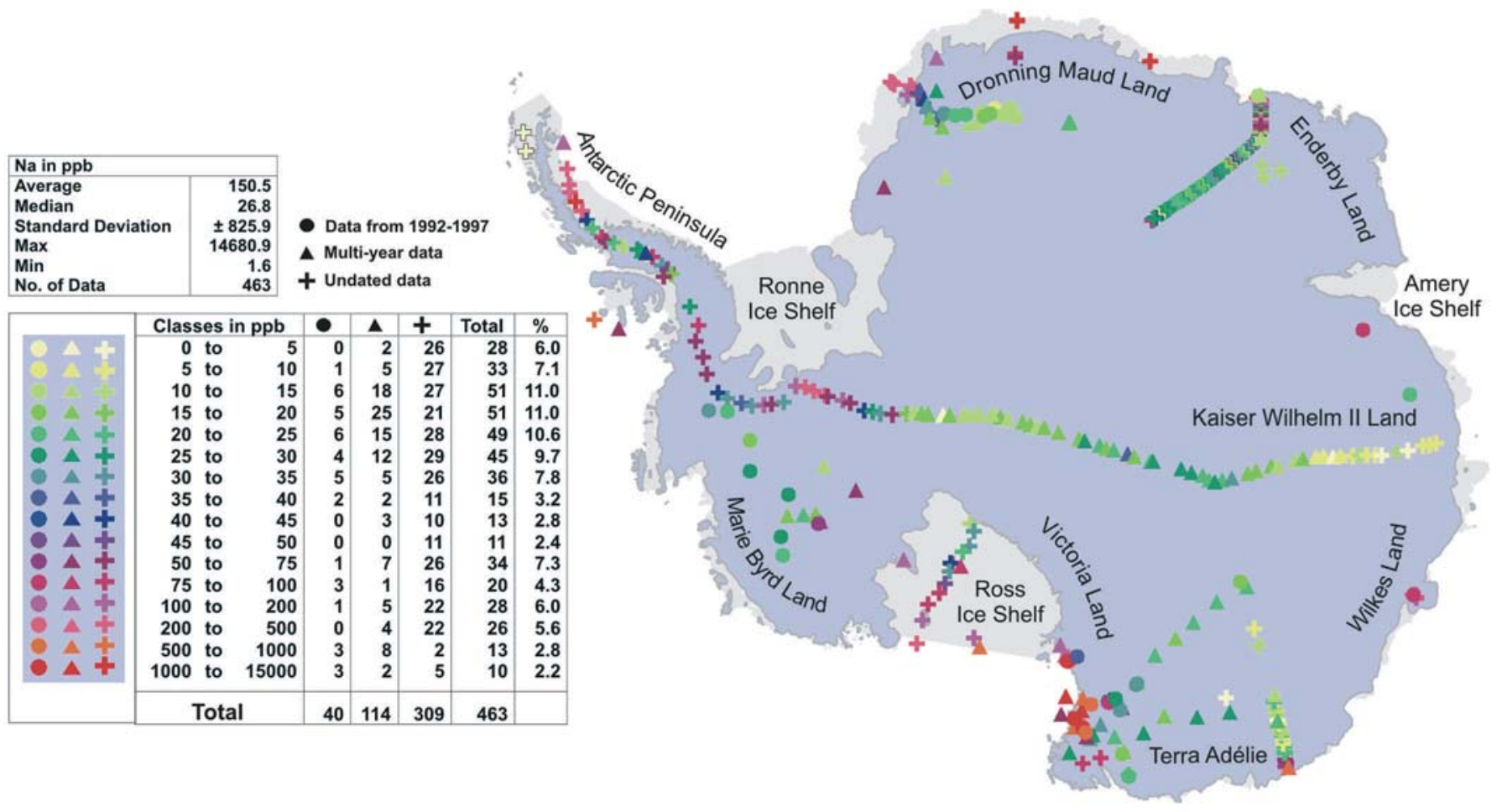

Fig. 3. Spatial variability of Na concentration measured in ppb. Solid circles represent 1992-97 data; solid triangles represent all other multiyear data. Crosses represent non-annual or undated samples.

Land and Terre Adélie). Furthermore, the change from very low to very high concentrations seems to occur within a narrow band in the vicinity of the coast. While high $\mathrm{Na}$ deposition is readily explained in coastal areas due to high sea-salt input, the narrow zone of marine air-mass intrusions (mesoscale cyclonic activity) coincides with the rapid decrease of $\mathrm{Na}$ concentrations in the Antarctic interior. Here the katabatic wind streams, transporting Na-depleted air masses from the interior towards the coast, compete with the Na-rich coastal air masses. In contrast, the Antarctic Peninsula shows overall high values and no trends, caused by strong sea-salt input all around and a secondary non-seasalt contribution from ice-free mountain peaks However, it is important to note that most of the data points located on the Antarctic Peninsula are surface samples representing winter snow. As $\mathrm{Na}$ peaks in most regions of Antarctica during winter, the higher $\mathrm{Na}$ concentrations reported from the Antarctic Peninsula are partially explained by this bias.

$\mathrm{Cl}$ variability exhibits a similar pattern to $\mathrm{Na}$ (Fig. 4), ranging from $\sim 1$ to $27740 \mathrm{ppb}$. The highest values are observed at coastal sites ( 150-27 740 ppb), and lower values in the interior ( 1 to $\sim 150 \mathrm{ppb}$ ). The Antarctic Peninsula again shows overall high values and no significant trend with elevation. Furthermore, $\mathrm{Cl}$ shows high concentrations in the centre of the East Antarctic interior, which are also observed in the $\mathrm{Na}$ data, but to a lesser degree. In Figure 5 the spatial variability of the $\mathrm{Cl} / \mathrm{Na}$ ratio is shown, ranging from 0.2 to 19.3. While most sites show a near-seawater ratio of 1.8 (Warneck, 1988), in the Antarctic interior the ratio increases to an average value of 4.3, with data ranging from 2 to 9 . Whereas coastal sites are likely to show sea-water $\mathrm{Cl} / \mathrm{Na}$ ratios due to the direct input, elevated $\mathrm{Cl}$ / $\mathrm{Na}$ ratio in the low-accumulation zones of the Antarctic interior are suggestive of secondary $\mathrm{Cl}$ precipitation through
$\mathrm{HCl}$ (De Angelis and Legrand, 1995), which might be partially offset by $\mathrm{HCl}$ re-emission from the upper layers of the snowpack (Udisti and others, 2004; Benassai and others, 2005). Overall, Antarctic interior $\mathrm{Cl}$ and $\mathrm{Na}$ concentrations are depleted in comparison to coastal values (Figs 3 and 4). However, in the East Antarctic interior, $\mathrm{Cl}$ seems relatively less depleted than $\mathrm{Na}$, causing an increase in the $\mathrm{Cl} / \mathrm{Na}$ ratio.

Figure 6 shows the spatial variability of $\mathrm{NO}_{3}$, ranging from $\sim 4$ to $\sim 800 \mathrm{ppb}$. Highest values can be observed in Enderby Land, Dronning Maud Land and Victoria Land, ranging from $\sim 30$ to $800 \mathrm{ppb}$. Intermediate values are reported from Marie Byrd Land, the Ronne Ice Shelf, the South Pole region and northern Victoria Land ( $235-$ $100 \mathrm{ppb})$, while the lowest values are observed on the Antarctic Peninsula and in Kaiser-Wilhelm-II. Land $(\sim 0-$ $20 \mathrm{ppb}$ ). While $\mathrm{NO}_{3}$ has been shown to be affected by postdepositional loss at low-accumulation sites (Mayewski and Legrand, 1990; De Angelis and Legrand, 1995; Legrand and Mayewski, 1997; Mulvaney and others, 1998), the lowest values for $\mathrm{NO}_{3}$ have been observed at sites with relatively high annual accumulation, namely the Antarctic Peninsula and Kaiser-Wilhelm-II. Land. Samples from those sites were collected from the snow surface during August-September 1989 and February 1990, respectively, and contrast with snow surface samples from Enderby Land collected during October 1997, which show some of the highest values in the entire dataset. This suggests that post-depositional loss of $\mathrm{NO}_{3}$ is strongly dependent on site-specific characteristics.

Spatial variability of $\mathrm{SO}_{4}$ is shown in Figure 7 . The data range from 0.1 to $3800 \mathrm{ppb}$. It is important to note that $\mathrm{SO}_{4}$ is particularly prone to sporadic input through volcanic events. As the dataset represents different time periods, some of which coincide with volcanic eruptions, it is necessary 


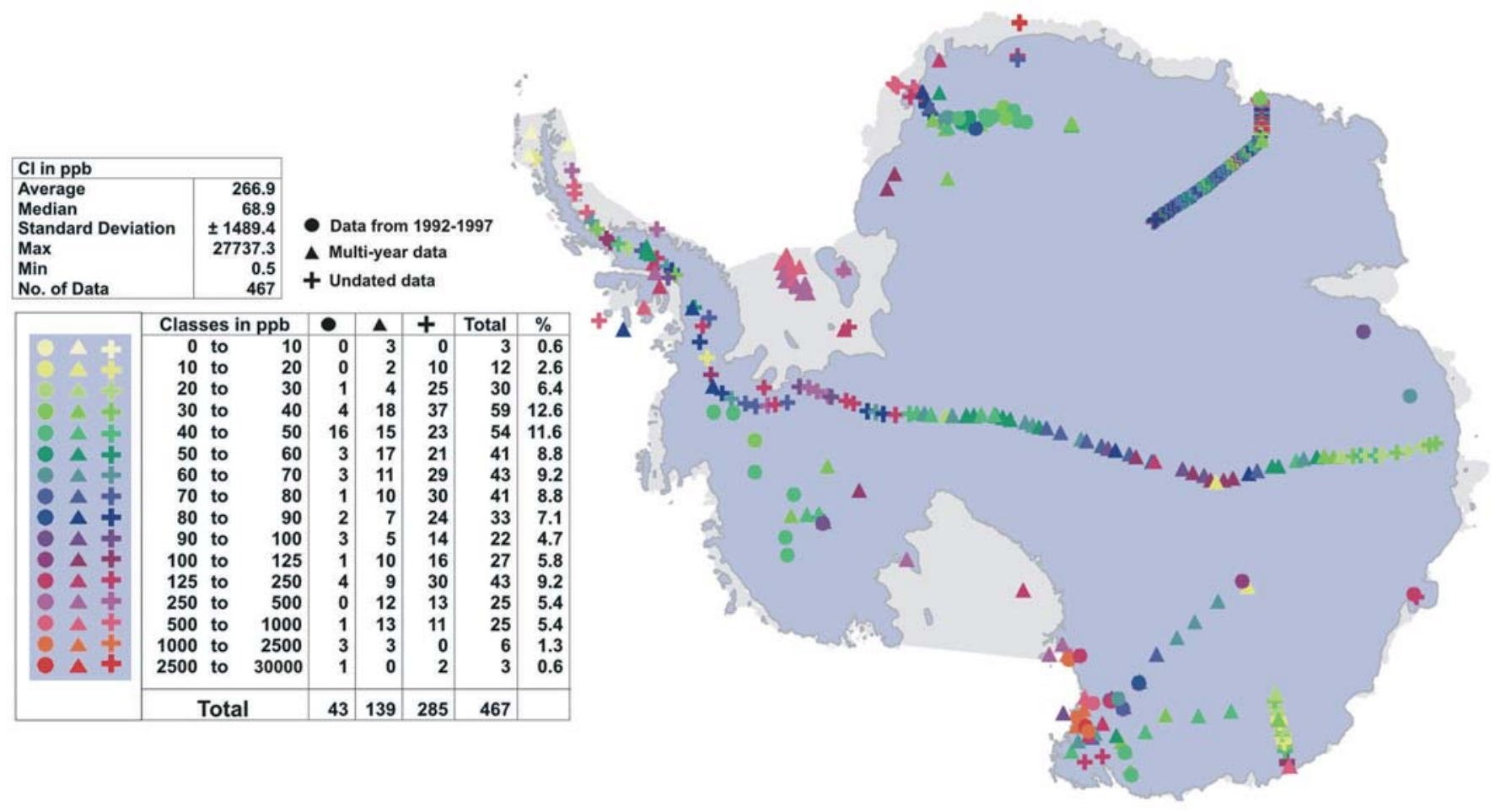

Fig. 4. Spatial variability of $\mathrm{Cl}$ concentration measured in ppb.

to interpret $\mathrm{SO}_{4}$ variability carefully. However, many data points in Marie Byrd Land, Victoria Land and Dronning Maud Land are contemporary data from 1992-97 (Fig. 7, solid circles). The $\mathrm{SO}_{4}$ concentrations of those data are higher in Victoria Land and Dronning Maud Land ( 30-3800 ppb) than in Marie Byrd Land ( 30-90 ppb).
Furthermore, the transect leading from the Antarctic Peninsula to Kaiser-Wilhelm-II. Land shows large variability. The Antarctic Peninsula is characterized by low values ( 10-30 ppb), with higher values only at coastal sites $(\sim 75-$ $1000 \mathrm{ppb}$ ). The values from Kaiser-Wilhelm-II. Land are also relatively low, at 15-70 ppb. The central part of the transect,

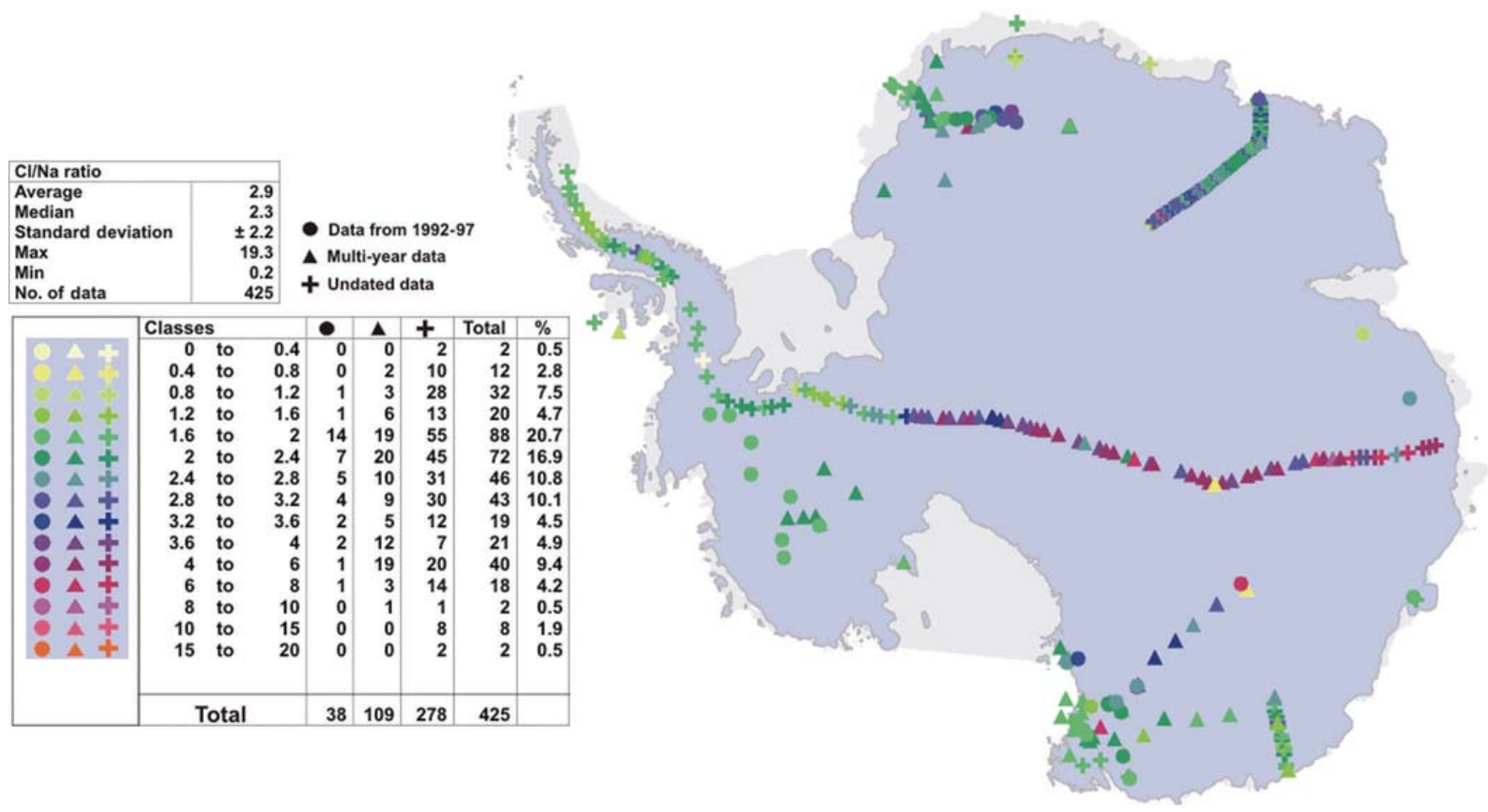

Fig. 5. Spatial variability of $\mathrm{Cl} / \mathrm{Na}$ ratio. 


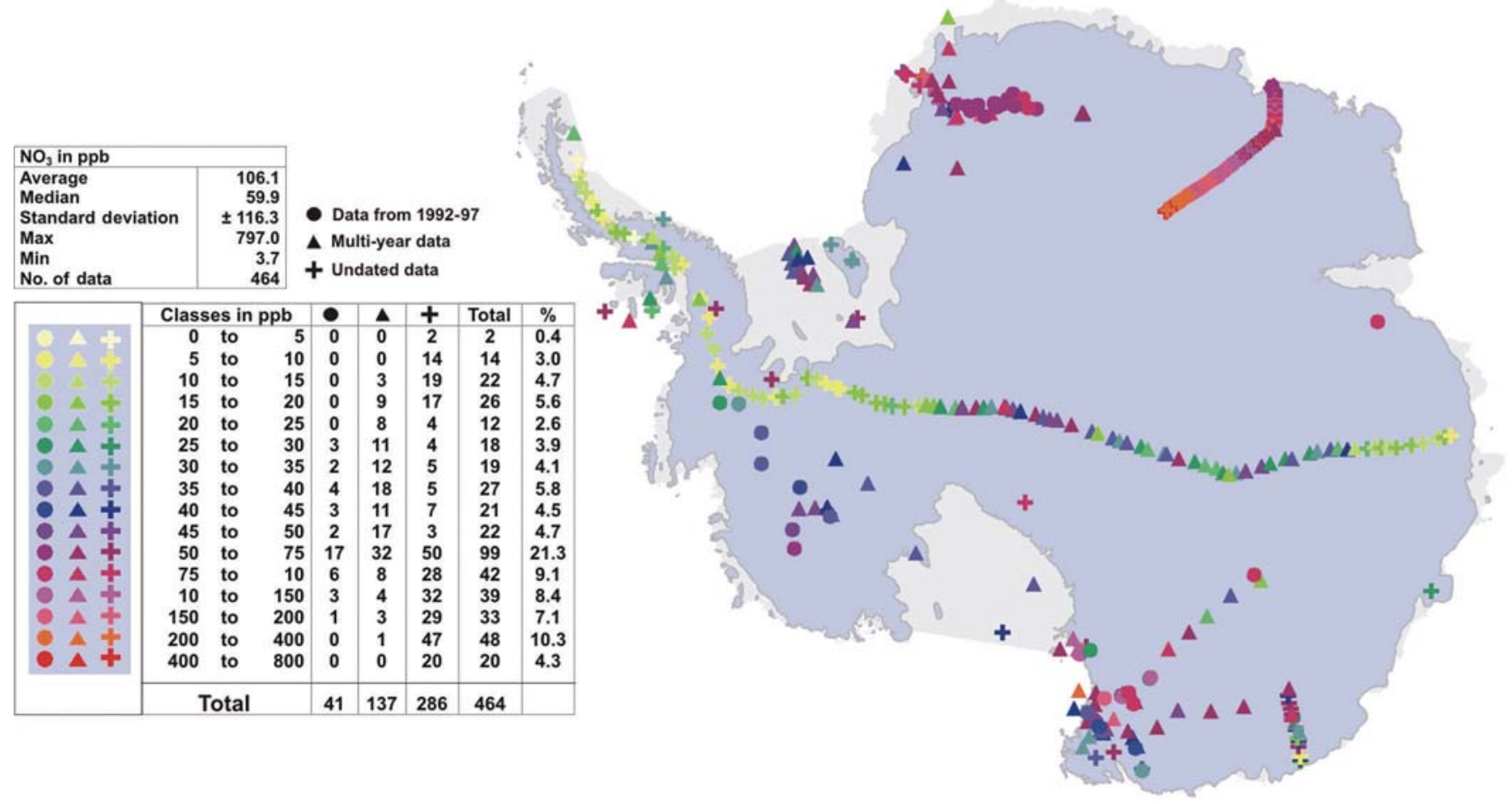

Fig. 6. Spatial variability of $\mathrm{NO}_{3}$ concentration measured in ppb.

however, shows comparatively high values ( 70-100 ppb). In addition, the Enderby Land transect shows an increase in $\mathrm{SO}_{4}$ concentration with elevation (from $\sim 10 \mathrm{ppb}$ to $30 \mathrm{ppb}$ ). This could be influenced by local accumulation rates and variable $\mathrm{SO}_{4}$ sources.

In Figure 8, spatial variability of MS data is shown, ranging from 3 to $166 \mathrm{ppb}$. In contrast to $\mathrm{NO}_{3}$ and $\mathrm{SO}_{4}, \mathrm{MS}$ is thought to be predominantly derived through wet deposition due to its high Henry constant (Udisti and others, 1998; Becagli and others, 2005). Overall, the data show highest concentration at coastal sites, with deceasing trends inland, except for two areas: the coastal sites at King George and Livingston Islands and the transect at Enderby Land. While MS concentrations in the former are unusually low compared to other coastal

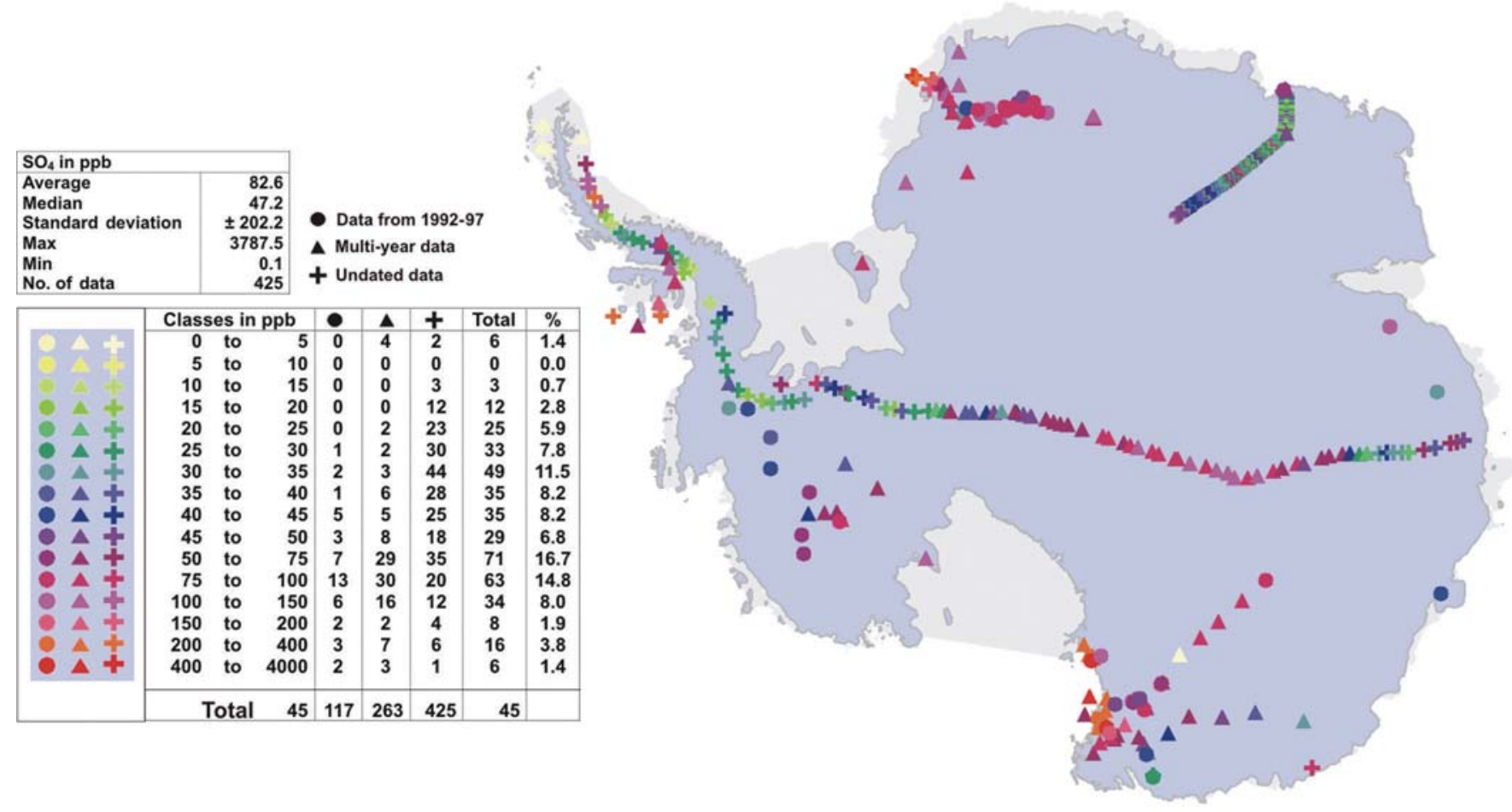

Fig. 7. Spatial variability of $\mathrm{SO}_{4}$ concentration measured in ppb. 


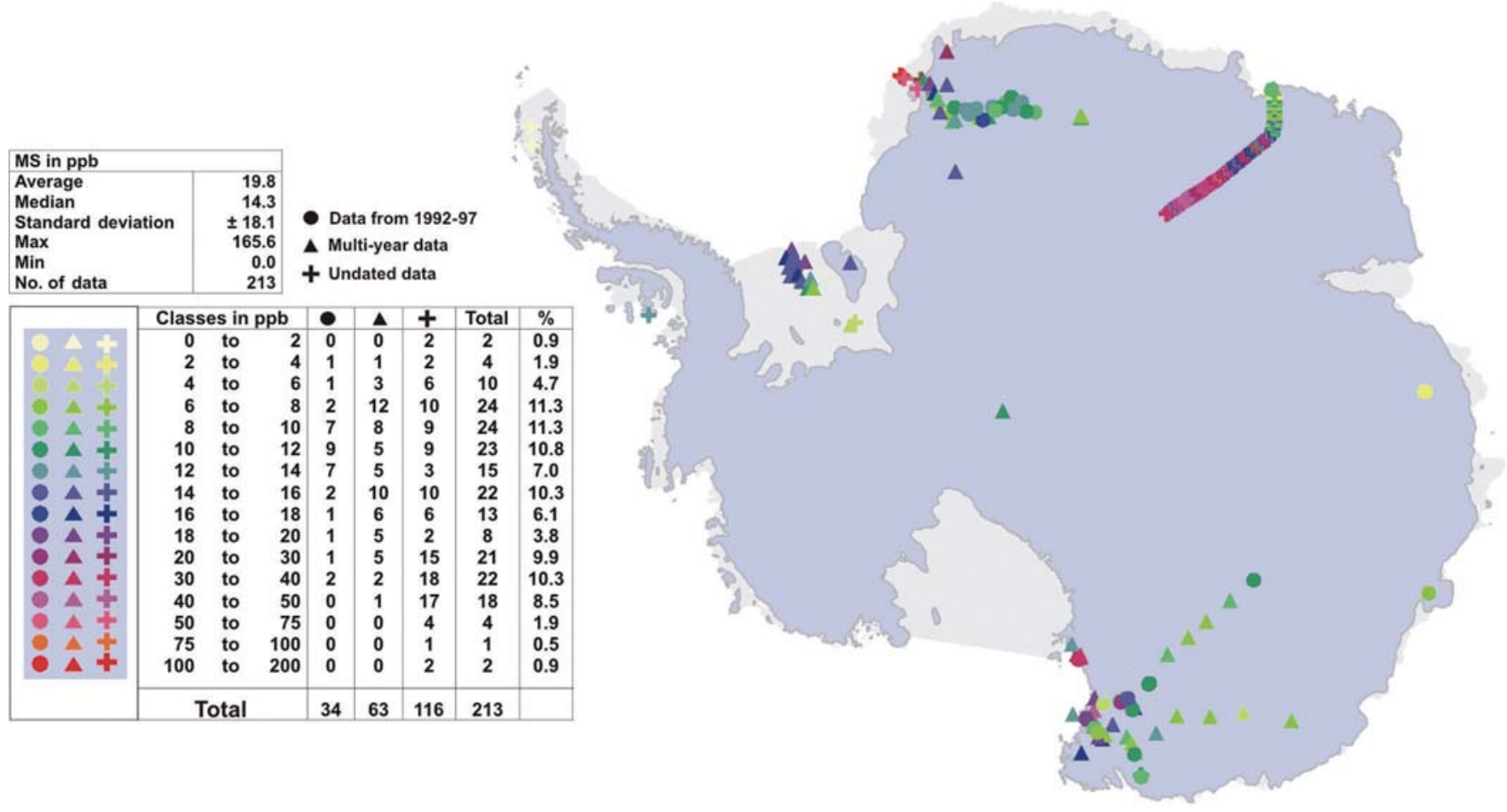

Fig. 8. Spatial variability of MS concentration measured in ppb.

sites ( $\sim 0-2 \mathrm{ppb})$, the latter shows a trend from low MS values (0-14 ppb) at low elevation to high MS concentrations (14$50 \mathrm{ppb}$ ) further inland. A similar but less pronounced increase in concentration along the Enderby Land transect is also observed in the $\mathrm{SO}_{4}$ and $\mathrm{NO}_{3}$ data.

$\mathrm{Ca}, \mathrm{Mg}$ and $\mathrm{K}$ are shown in Figures 9-11, respectively. Concentration values range from 0.1 to $740 \mathrm{ppb}$ for $\mathrm{Ca}$, from
0.2 to $1930 \mathrm{ppb}$ for $\mathrm{Mg}$, and from 0.1 to $600 \mathrm{ppb}$ for K. All three species show overall low concentration values across Antarctica, with a few exceptions. Local dust sources such as the McMurdo Dry Valleys, a strong marine influence such as Terra Nova, or coastal sites at the Antarctic Peninsula cause orders-of-magnitude higher concentrations. Intermediate concentration levels are rare. The continent-wide

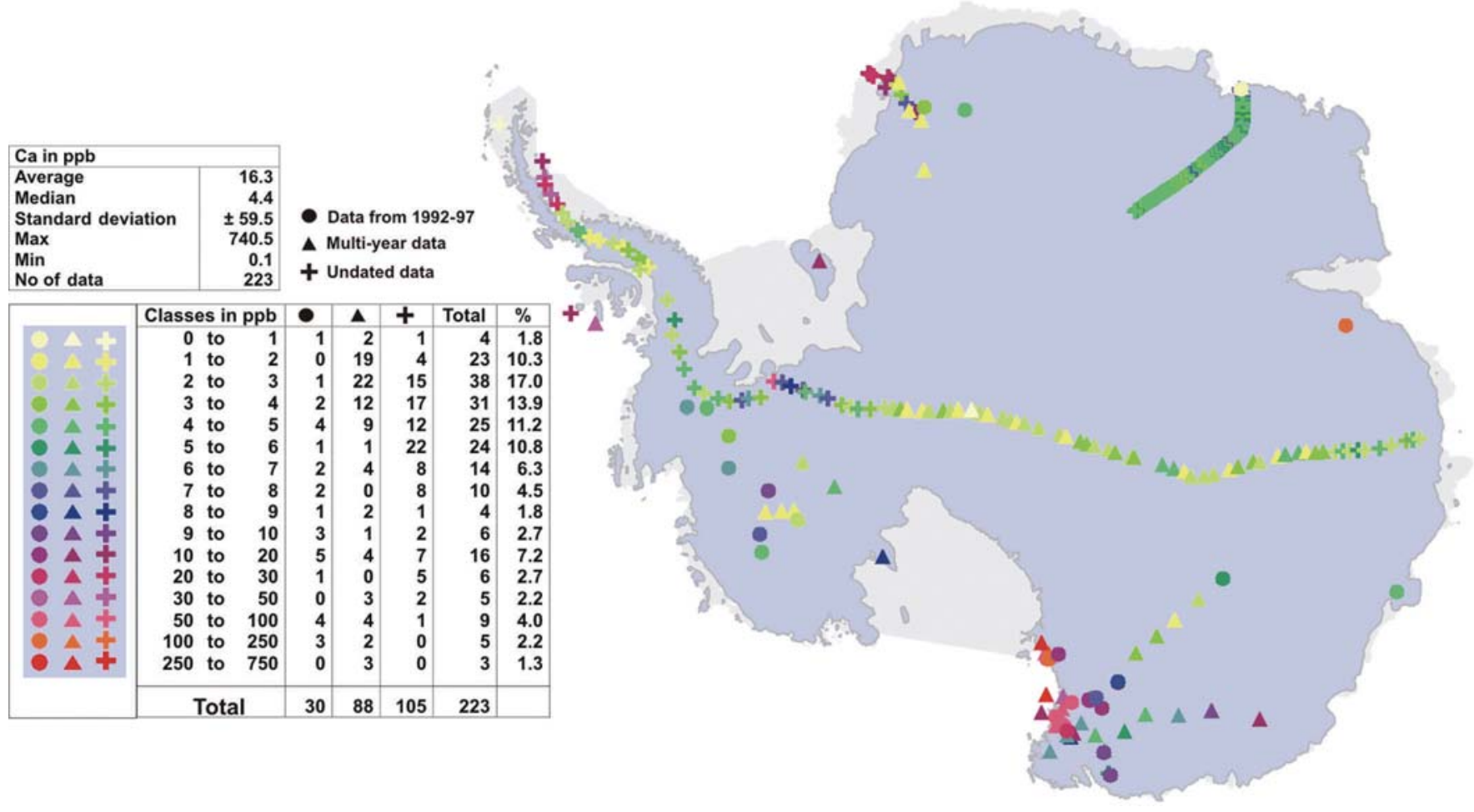

Fig. 9. Spatial variability of Ca concentration measured in ppb. 


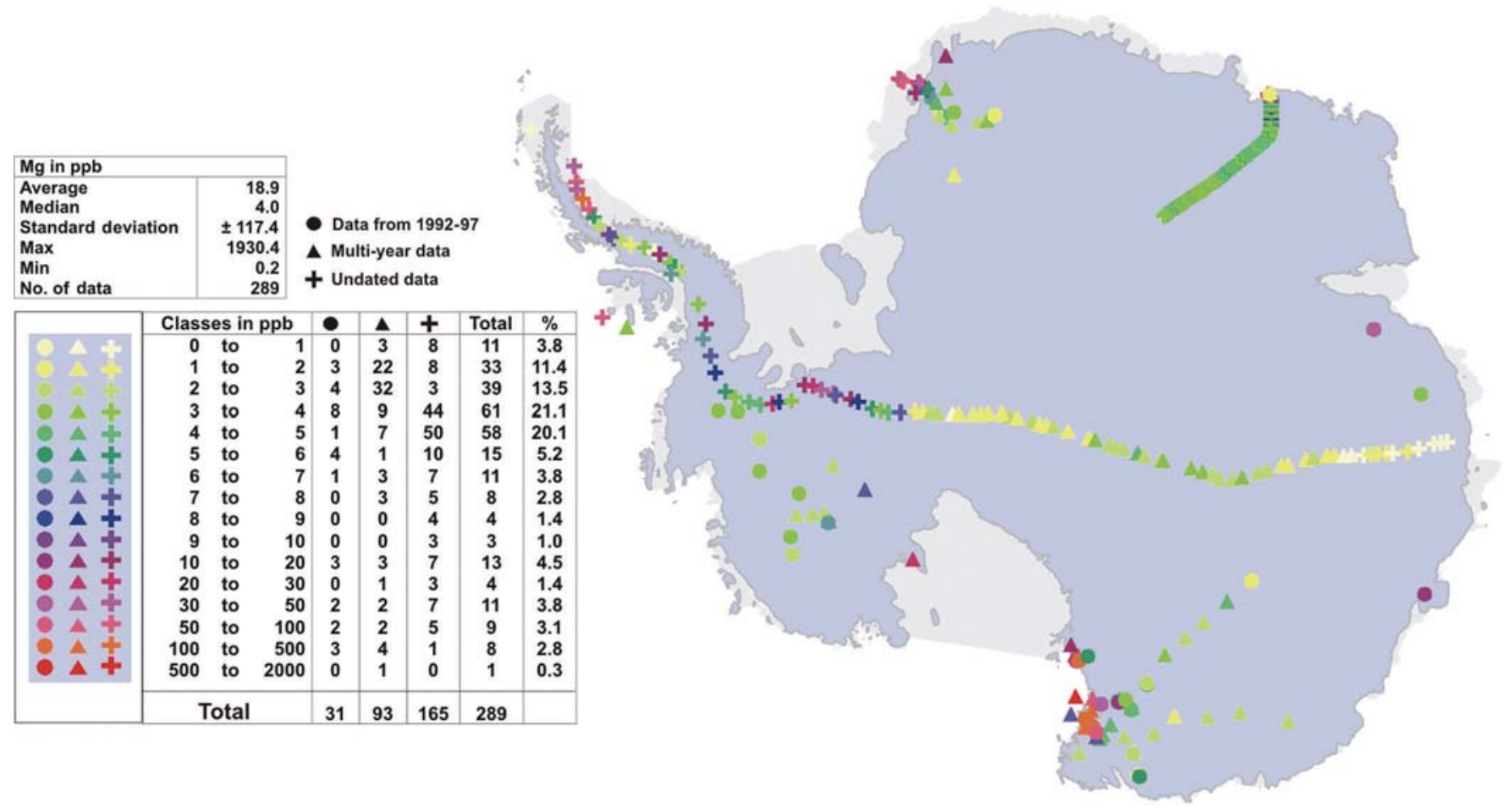

Fig. 10. Spatial variability of $M g$ concentration measured in ppb.

pattern might therefore be used to distinguish typical 'global' or hemispherical dust content from local Antarctic sources.

\section{SUGGESTIONS FOR FUTURE WORK}

The primary objectives of this paper are to provide an updated summary of available chemistry data from Antarctica and make recommendations for future efforts. The observed variability across Antarctica clearly shows the need for an improved understanding of the mechanisms that ultimately control the chemistry of a snow or ice sample. By making this dataset available, we invite and encourage the wider science community to participate in this continentwide effort.

Based on our findings and on previous papers, we aim for the following research outputs as the next step for the ITASE Chemistry Synthesis group:

Investigation of the snow chemistry signal migration and spatial variability of significant climate events and oscillating and non-oscillating climate drivers

This can be achieved by intercontinental comparison of snow chemistry variability contrasting, for example, El Niño with La Niña years, high-index Antarctic Oscillation years with low-index years, and the snow chemistry signal before, during and after volcanic eruptions

Furthermore, cross-correlation of snow chemistry data with re-analysis data, such as NCEP/NCAR (US National Centers for Environmental Prediction/US National Center for Atmospheric Research) and ERA-40 (European reanalysis), will allow us to link characteristic geographic chemistry patterns to typical climate modes, establishing transfer functions, and to identify Antarctic teleconnections and their variability through time
Tuning general circulation models to reconstruct snow chemistry patterns in recurring synoptic and mesoscale climate events, using contemporary chemistry data as a training set, will allow us to use these models in reverse, to output climate events using chemistry data further back in time.

Investigation of the relationship between atmospheric aerosol loading and contemporary snow chemistry

Quantification of contemporary aerosol precipitation and deposition efficiency by linking surface snow chemistry concentration with atmospheric aerosol loading measurements can be established in collaboration with the ITASE Atmospheric Chemistry Synthesis group. Furthermore, this will assist in investigating the processes that lead to post-depositional ion concentration changes. It is important to compare samples of similar age as well as of similar snow depths

Investigation of dry vs wet deposition is particularly important when comparing coastal sites with the Antarctic interior. Here progress can be achieved in collaboration with the ITASE/ISMASS Mass Balance Synthesis group and the ITASE Atmospheric Chemistry Synthesis group

Incorporate new analytical techniques allowing the measurement of trace elements and their isotopic signatures, as well as organic acids, and particles.

\section{Laboratory inter-comparison}

We suggest a laboratory inter-comparison in order to demonstrate the compatibility of snow chemistry data across all laboratories. 


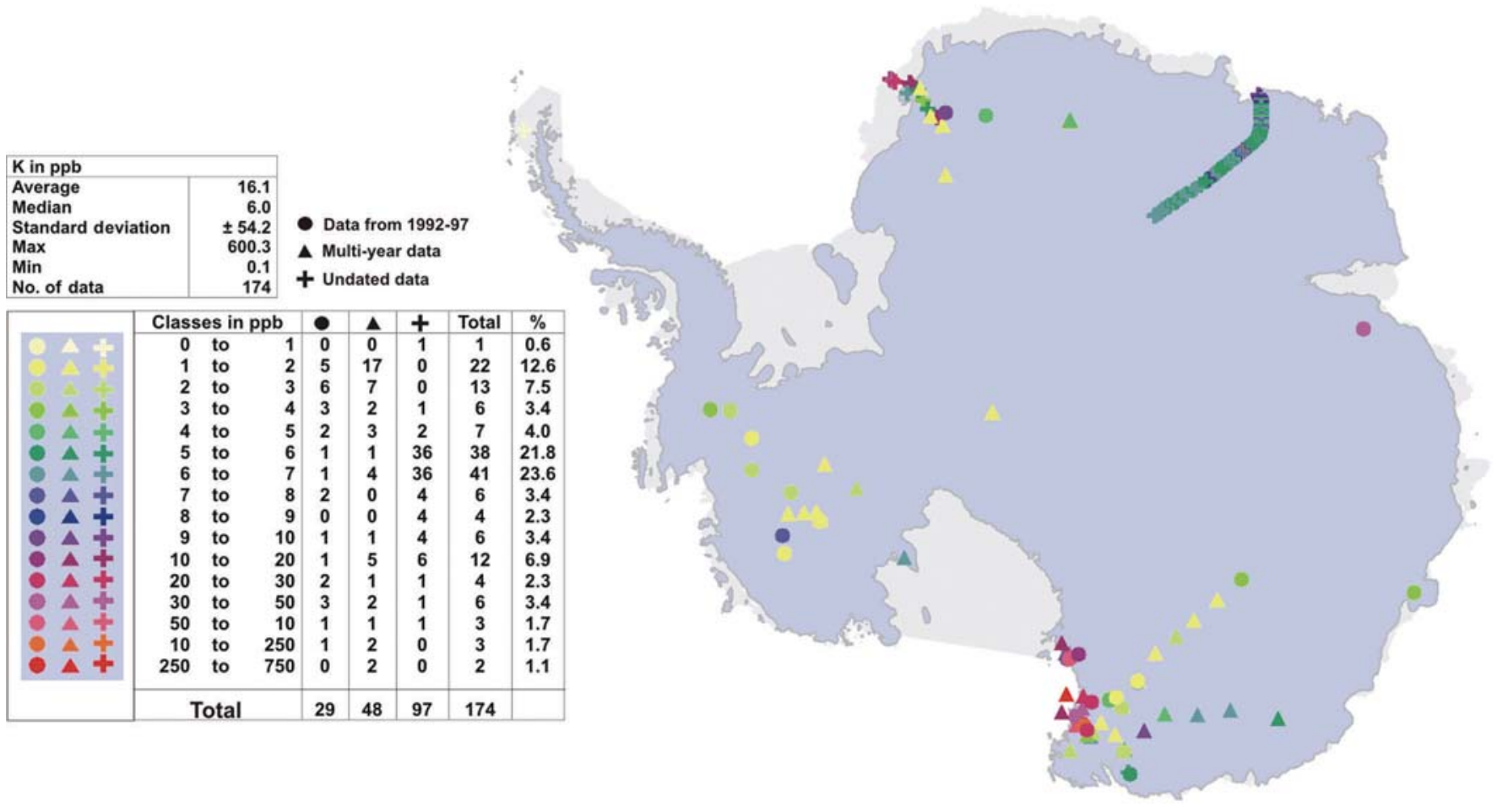

Fig. 11. Spatial variability of $K$ concentration measured in $p p b$.

\section{Data availability}

The data described here are made available through the ITASE web page. The dataset will be updated as new data and datasets are provided.

\section{ACKNOWLEDGEMENTS}

We thank the Scientific Committee on Antarctic Research, the national Antarctic programmes and the national funding sources for their support. Two anonymous reviewers made helpful comments that improved the manuscript.

\section{REFERENCES}

Aristarain, A. and R.J. Delmas. 2002. Snow chemistry measurements on James Ross Island (Antarctic Peninsula) showing seasalt aerosol modifications. Atmos. Environ., 36, 765-772.

Becagli, S. and 12 others. 2004. Chemical and isotopic snow variability in East Antarctica along the 2001/02 ITASE traverse. Ann. Glaciol., 39, 473-482.

Becagli, S. and 6 others. 2005. Spatial distribution of biogenic sulphur compounds (MSA, nssSO ${ }_{4}{ }^{2-}$ ) in the northern Victoria Land-Dome C-Wilkes Land area, East Antarctica. Ann. Glaciol., 41 (see paper in this volume).

Benassai, S. and 7 others. 2005. Sea-spray deposition in Antarctic coastal and plateau areas from ITASE traverses. Ann. Glaciol., 41 (see paper in this volume).

Bertler, N.A.N., P.J. Barrett, P.A. Mayewski, R.L. Fogt, K.J. Kreutz and J. Shulmeister. 2004a. El Niño suppresses Antarctic warming. Geophys. Res. Lett., 31(15), L15207. (10.1029/ 2004GL020749.)

Bertler, N.A.N., P.A. Mayewski, P.J. Barrett, S.B. Sneed, M.J. Handley and K.J. Kreutz. 2004b. Monsoonal circulation of the McMurdo Dry Valleys, Ross Sea region: signal from the snow chemistry. Ann. Glaciol., 39, 139-145.

Bertler, N.A.N., P.A. Mayewski, S.B. Sneed, T.R. Naish, U. Morgenstern and P.J. Barrett. 2005. Solar forcing recorded by aerosol concentrations in coastal Antarctic glacier ice, McMurdo Dry Valleys. Ann. Glaciol., 41 (see paper in this volume).

Clausen, H.B. 1995. Group meeting on nitrate sources in Antarctica and Greenland. In Delmas, R.J., ed. Ice core studies of global biogeochemical cycles. Berlin, etc., Springer-Verlag, 247-248. (NATO ASI Series I: Global Environmental Change 30.)

Curran, M.A.J., T.D. van Ommen and V. Morgan. 1998. Seasonal characteristics of the major ions in the high-accumulation Dome Summit South ice core, Law Dome, Antarctica. Ann. Glaciol., 27, 385-390.

De Angelis, M. and M. Legrand. 1995. Preliminary investigations of post depositional effects of $\mathrm{HCl}, \mathrm{HNO}_{3}$, and organic acids in polar firn layers. In Delmas, R.J., ed. Ice core studies of global biogeochemical cycles. Berlin, SpringerVerlag, 361-381. (NATO ASI Series I: Global Environmental Change 30.)

Delmas, R.J., J.M. Barnola and M. Legrand. 1982. Gas-derived aerosol in central Antarctic snow and ice: the case of sulphuric and nitric acids. Ann. Glaciol., 3, 71-76.

Delmas, R.J., P. Wagnon, K. Goto-Azuma, K. Kamiyama and O. Watanabe. 2003. Evidence for the loss of snow-deposited MSA to the interstitial gaseous phase in central Antarctic firn. Tellus, 55B(1), 71-79.

Dixon, D., P.A. Mayewski, S. Kaspari, S. Sneed and M. Handley. 2004. A 200 year sub-annual record of sulfate in West Antarctica from 16 ice cores. Ann. Glaciol., 39, 545-556.

EPICA community. 2004. Eight glacial cycles from an Antarctic ice core. Nature, 429(6992), 623-628.

Evans, W.J.F., C.T. McElroy and I.E. Galbally. 1985. The conversion of $\mathrm{N}_{2} \mathrm{O}_{5}$ to $\mathrm{HNO}_{3}$ at high latitudes in winter. Geophys. Res. Lett., 12(12), 825-828.

Gayley, R.I. and M. Ram. 1985. Atmospheric dust in polar ice and the background aerosol. J. Geophys. Res., 90(D7), 12,92112,925 .

Gow, A.J. 1965. On the accumulation and seasonal stratification of snow at the South Pole. J. Glaciol., 5(40), 467-477.

Jones, A.E. and 6 others. 2001. Measurements of $\mathrm{NO}_{\mathrm{x}}$ emissions from the Antarctic snowpack. Geophys. Res. Lett., 28(8), 1499-1502. 
Kaspari, S., P.A. Mayewski, D.A. Dixon, S.B. Sneed and M.J. Handley. 2005. Sources and transport pathways of marine aerosol species into West Antarctica. Ann. Glaciol., 41 (see paper in this volume).

Kreutz, K.J. and P.A. Mayewski. 1999. Spatial variability of Antarctic surface snow glaciochemistry: implications for paleoatmospheric circulation reconstructions. Antarct. Sci., 11(1), 105-118.

Kreutz, K.J., P.A. Mayewski, S.I. Whitlow and M.S. Twickler. 1998. Limited migration of soluble ionic species in a Siple Dome, Antarctica, ice core. Ann. Glaciol., 27, 371-377.

Kreutz, K.J. and 11 others. 1999. Seasonal variations of glaciochemical, isotopic and stratigraphic properties in Siple Dome (Antarctica) surface snow. Ann. Glaciol., 29, 38-44.

Kreutz, K.J., P.A. Mayewski, L.D. Meeker, M.S. Twickler and S.I. Whitlow. 2000. The effect of spatial and temporal accumulation rate variability in West Antarctica on soluble ion deposition. Geophys. Res. Lett., 27(16), 2517-2520.

Legrand, M. 1995. Sulphur-derived species in polar ice: a review. In Delmas, R.J., ed. Ice core studies of global biogeochemical cycles. Berlin, Springer-Verlag, 91-119. (NATO ASI Series I: Global Environmental Change 30.)

Legrand, M. and R.J. Delmas. 1986. Relative contributions of tropospheric and stratospheric sources to nitrate in Antarctic snow. Tellus, 38B(3-4), 236-249.

Legrand, M.R. and S. Kirchner. 1990. Origins and variations of nitrate in south polar precipitation. J. Geophys. Res., 95(D4), 3493-3507.

Legrand, M. and P. Mayewski. 1997. Glaciochemistry of polar ice cores: a review. Rev. Geophys., 35(3), 219-243.

Liu, H., K.C. Jezek, B. Li and Z. Zhao. 2001. RADARSAT Antarctic Mapping Project digital elevation model version 2. Boulder, CO, National Snow and Ice Data Center.

Mayewski, P.A. and M. Legrand. 1990. Recent increase in nitrate concentration of Antarctic snow. Nature, 346(6281), 258-260.

Mayewski, P.A. and F. White. 2002. The ice chronicles. Hanover, $\mathrm{NH}$, University Press of New England.

Mayewski, P.A., W.B. Lyons, M.J. Spencer, M.S. Twickler, C.F. Buck and S. Whitlow. 1990. An ice core record of atmospheric response to anthropogenic sulphate and nitrate. Nature, 346(6284), 554-556.

Mayewski, P.A., M.J. Spencer and W.B. Lyons. 1992. A review of glaciochemistry with particular emphasis on the recent record of sulfate and nitrate. In Moore, B. and S. David, eds. Proceedings of the 1988 OIED Global Change Institute: Trace Gases and the Biosphere. Boulder, CO, University Corporation for Atmospheric Research/Office of Interdisciplinary Earth Studies, 177-199.

Mayewski, P.A. and 11 others. 1995. An ice-core-based, Late Holocene history for the Transantarctic Mountains, Antarctica. In Elliot, D.H. and G.L. Blaisdell, eds. Contributions to Antarctic research IV. Washington, DC, American Geophysical Union, 33-45. (Antarctic Research Series 67.)

McKenzie, R.L. and P.V. Johnston. 1984. Springtime stratospheric $\mathrm{NO}_{2}$ in Antarctica. Geophys. Res. Lett., 11(1), 73-75.

Meyerson, E.A., P.A. Mayewski, K.J. Kreutz, L.D. Meeker, S.I. Whitlow and M.S. Twickler. 2002. The polar expression of ENSO and sea-ice variability as recorded in a South Pole ice core. Ann. Glaciol., 35, 430-436.

Minikin, A. and 7 others. 1998. Sulfur-containing species (sulfate and methanesulfonate) in coastal Antarctic aerosol and precipitation. J. Geophys. Res., 103(D9), 10,975-10,990.

Mulvaney, R. and D.A. Peel. 1988. Anions and cations in ice cores from Dolleman Island and the Palmer Land plateau, Antarctic Peninsula. Ann. Glaciol., 10, 121-125.

Mulvaney, R. and E.W. Wolff. 1994. Spatial variability of the major chemistry of the Antarctic ice sheet. Ann. Glaciol., 20, 440-447.

Mulvaney, R., E.C. Pasteur, D.A. Peel, E.S. Saltzman and P.Y. Whung. 1992. The ratio of MSA to non-sea-salt sulphate in Antarctic Peninsula ice cores. Tellus, 44B(4), 295-303.
Mulvaney, R., D. Wagenbach and E. Wolff. 1998. Postdepositional change in snowpack nitrate from observation of year-round nearsurface snow in coastal Antarctica. J. Geophys. Res., 103(D9), $11,021-11,031$.

Palmer, A.S., T.D. van Ommen, M.A.J. Curran and V. Morgan. 2001. Ice-core evidence for a small solar-source of atmospheric nitrate. Geophys. Res. Lett., 28(10), 1953-1956.

Parker, B.C. and E.J. Zeller. 1980. Nitrogenous chemical composition of Antarctic snow and ice. Antarct. J. US, 15(5), 79-81.

Parker, B.C., E.J. Zeller and A.J. Gow. 1981. Nitrogenous chemical composition of Antarctic snow and ice. Antarct. J. US, 16(5), 79-81.

Parker, B.C., G.A.M. Dreschhoff, C.M. Laird and E.J. Zeller. 1982. Nitrates in South Pole snow. Antarct. J. US, 17(5), 88-89.

Proposito, M. and 9 others. 2002. Chemical and isotopic snow variability along the 1998 ITASE traverse from Terra Nova Bay to Dome C, East Antarctica. Ann. Glaciol., 35, 187-194.

Qin, D., E.J. Zeller and G.A.M. Dreschhoff. 1992. The distribution of nitrate content in the surface snow of the Antarctic ice sheet along the route of the 1990 International Trans-Antarctic Expedition. J. Geophys. Res., 97(A5), 6277-6284.

Röthlisberger, R., M.A. Hutterli, S. Sommer, E.W. Wolff and R. Mulvaney. 2000. Factors controlling nitrate in ice cores: evidence from the Dome C deep ice core. J. Geophys. Res., 105(D16), 20,565-20,572.

Röthlisberger, R. and 10 others. 2002. Nitrate in Greenland and Antarctic ice cores: a detailed description of post-depositional processes. Ann. Glaciol., 35, 209-216.

Saltzman, E.S. 1995. Ocean/atmosphere cycling of dimethylsulfide. In Delmas, R.J., ed. Ice core studies of global biogeochemical cycles. Berlin, etc., Springer-Verlag, 65-90. (NATO ASI Series I: Global Environmental Change 30.)

Saltzman, E.S., P.Y. Whung and P. Mayewski. 1997. Methanesulfonate in the Greenland Ice Sheet Project 2 ice core. J. Geophys. Res., 102(C12), 26,649-26,657.

Shaw, G.E. 1979. Consideration on the origin and optical properties of the Antarctic aerosol. Rev. Geophys. Space Phys., 17(8), 1983-1998.

Sigg, A. and A. Neftel. 1988. Seasonal variations in hydrogen peroxide in polar ice cores. Ann. Glaciol., 10, 157-162.

Solomon, S. and J.G. Keys. 1992. Seasonal variations in Antarctic $\mathrm{NO}_{x}$ chemistry. J. Geophys. Res., 97(D8), 7971-7978.

Stenberg, M. and 7 others. 1998. Spatial variability of snow chemistry in western Dronning Maud Land, Antarctica. Ann. Glaciol., 27, 378-384.

Stenberg, M., M. Hansson, P. Holmlund and L. Karlöf. 1999. Variability in snow layering and snow chemistry in the vicinity of two drill sites in western Dronning Maud Land, Antarctica. Ann. Glaciol., 29, 33-37.

Toon, O.B., P. Hamill, R.P. Turco and J.O. Pinto. 1986. Condensation of $\mathrm{HNO}_{3}$ and $\mathrm{HCl}$ in the winter polar stratospheres. Geophys. Res. Lett., 13(12), 1284-1287.

Udisti, R., R. Traversi, S. Becagli and G. Piccardi. 1998. Spatial distribution and seasonal pattern of biogenic sulphur compounds in snow from northern Victoria Land, Antarctica. Ann. Glaciol., 27, 535-542.

Udisti, R., S. Becagli, E. Castellano, R. Traversi, S. Vermigli and G. Piccardi. 1999. Sea-spray and marine biogenic seasonal contribution to snow composition at Terra Nova Bay, Antarctica. Ann. Glaciol., 29, 77-83.

Udisti, R. and 7 others. 2004. Atmosphere-snow interaction by a comparison between aerosol and uppermost snow layers composition at Dome C (East Antarctica). Ann. Glaciol., 39, 53-65.

Wagenbach, D. 1996. Coastal Antarctica: atmospheric chemical composition and atmospheric transport. In Wolff, E.W. and R.C. Bales, eds. Chemical exchange between the atmosphere and polar snow. Berlin, etc., Springer-Verlag, 173-199. (NATO ASI Series I: Global Environmental Change 43.) 
Wagenbach, D., M. Legrand, H. Fischer, F. Pichlermayer and E. Wolff. 1998a. Atmospheric near-surface nitrate at coastal Antarctic sites. J. Geophys. Res., 103(D9), 11,00711,020 .

Wagenbach, D. and 7 others. 1998b. Sea-salt aerosol in coastal Antarctic regions. J. Geophys. Res., 103(D9), 10,96110,974

Wagnon, P., R.J. Delmas and M. Legrand. 1999. Loss of volatile acid species from upper firn layers at Vostok, Antarctica. J. Geophys. Res., 104(D3), 3423-3431.

Warneck, P. 1988. Chemistry of the natural atmosphere. San Diego, CA, Academic Press.

Welch, K., P.A. Mayewski and S.I. Whitlow. 1993. Methanesulfonic acid in coastal Antarctic snow related to sea-ice extent Geophys. Res. Lett., 20(6), 443-446.

Weller, R., F. Traufetter, H. Fischer, H. Oerter, C. Peel and H. Miller. 2004. Post-depositional losses of methane sulfonate nitrate and chlorine at the EPICA deep-drilling site in Dronning Maud Land, Antarctica. J. Geophys. Res., 109(D7), D07301. (10.1029/ 2003JD004189.)

Wolff, E.W. 1995. Nitrate in polar ice. In Delmas, R.J., ed. Ice core studies of global biogeochemical cycles. Berlin, etc., SpringerVerlag, 195-224. (NATO ASI Series I: Global Environmental Change 30.)

Wolff, E.W. and R. Mulvaney. 1991. Reactions on sulphuric acid aerosol and on polar stratospheric clouds in the Antarctic stratosphere. Geophys. Res. Lett., 18, 1007-1010.
Wolff, E.W., M.R. Legrand and D. Wagenbach. 1998a. Coastal Antarctic aerosol and snowfall chemistry. J. Geophys. Res., 103(D9), 10,927-10,934.

Wolff, E.W., D. Wagenbach, E.C. Pasteur, R. Mulvaney, M. Legrand and J.S. Hall. 1998b. Relationship between chemistry of air, fresh snow and firn cores for aerosol species in coastal Antarctica. J. Geophys. Res., 103(D9), 11,057-11,070.

Wolff, E.W., J.S. Hall, R. Mulvaney, E.C. Pasteur, D. Wagenbach and M. Legrand. 2002. Modelling photochemical $\mathrm{NO}_{x}$ production and nitrate loss in the upper snowpack of Antarctica. Geophys. Res. Lett., 29(20), 1944. (10.1029/2002GL015823.)

Xiao, C., P.A. Mayewski, D. Qin, Z. Li, M. Zhang and Y. Yan. 2004. Sea level pressure variability over the southern Indian Ocean inferred from a glaciochemical record in Princess Elizabeth Land, east Antarctica. J. Geophys. Res., 109(D16), D16101. (10.1029/2003JD004065.)

Yang, Q., P.A. Mayewski, E. Linder, S. Whitlow and M. Twickler. 1996a. Chemical species spatial distribution and relationship to elevation and snow accumulation rate over the Greenland ice sheet. J. Geophys. Res., 101(D13), 18,629-18,637.

Yang, Q., P.A. Mayewski, G.A. Zielinski, M. Twickler and K.C. Taylor. 1996b. Depletion of atmospheric nitrate and chloride as a consequence of the Toba volcanic eruption. Geophys. Res. Lett., 23(18), 2513-2516.

Zielinski, G.A. and 7 others. 1997. Volcanic aerosol records and tephrochronology of the Summit, Greenland, ice cores. J. Geophys. Res., 102(C12), 26,625-26,640. 